\title{
Small range and distinct distribution in a satellite breeding colony of the critically endangered Waved Albatross
}

\author{
Jill A. Awkerman • Sebastian Cruz • Carolina Proaño • Kathryn P. Huyvaert • \\ Gustavo Jiménez Uzcátegui • Andres Baquero • Martin Wikelski • \\ David J. Anderson
}

\begin{abstract}
To determine the proximate consequences of the limited breeding distribution of the critically endangered Waved Albatross (Phoebastria irrorata), we present continuous breeding season GPS tracks highlighting differences in behaviour, destinations, and distances travelled between three distinct colonies: two in Galápagos and one closer to the South American continent on Isla de la Plata, where a small number of pairs nest. Accelerometer data paired with GPS locations allowed operational classifications of Waved Albatross behaviour. All birds from Galápagos travelled eastward to the continental shelf and foraged southward along the Peruvian coast. Birds from Isla de la Plata made more and shorter foraging trips and used habitat north of the destinations of Galápagos birds. La Plata birds foraged in areas through which Galápagos
\end{abstract}

J. A. Awkerman ( $ه)$

US Environmental Protection Agency, Gulf Ecology Division,

Gulf Breeze, FL 32561, USA

e mail: Awkerman.Jill@epa.gov

S. Cruz $\cdot$ C. Proano $\cdot$ M. Wikelski

Max Planck Institute for Ornithology, Schlossallee 2, 78315 Radolfzell, Germany

K. P. Huyvaert

Department of Fish, Wildlife, and Conservation Biology, Colorado State University, Fort Collins, CO 80523, USA

\section{G. J. Uzcátegui}

Estación Científica Charles Darwin, Puerto Ayora, Galapágos, Ecuador birds commuted, and had slower average flight speeds and shorter commutes. Overall, albatrosses from La Plata might operate under a consistently lower return but they also incur lower costs compared to birds from Galápagos, which take fewer trips involving longer time investment. Galápagos birds may be able to forage more effectively based on more abundant or more profitable food patches in those highly productive areas. Foraging destinations of birds from the two Galápagos colonies were similar and overlapped areas that presented localized mortality risk from artisanal fisheries in previous years. This study, performed across the species' breeding range, reveals the different foraging distribution of La Plata albatrosses and the potential conservation value of this small colony in terms of maintenance of spatial diversity and behavioural plasticity.

Keywords Galápagos · La Plata · Seabird . Tracking · GPS · Accelerometer

\author{
A. Baquero \\ Universidad San Francisco de Quito, Quito, Ecuador \\ M. Wikelski \\ Konstanz University, 78457 Constance, Germany \\ D. J. Anderson \\ Department of Biology, Wake Forest University, \\ Winston Salem, NC 27109, USA
}




\section{Zusammenfassung}

\section{Kleines Verbreitungsgebiet und klar abgegrenzte Ver- teilung einer Satelliten-Brutkolonie des vom Aussterben bedrohten Galapagosalbatros}

Um die unmittelbaren Folgen der begrenzten Brutverbreitung des vom Aussterben bedrohten Galapagosalbatros (Phoebastria irrorata) zu ermitteln, stellen wir hier kontinuierliche GPS-Streckenaufzeichnungen zur Brutzeit vor, welche Unterschiede im Verhalten, den Flugzielen und den jeweils zurückgelegten Wegen zwischen drei separaten Kolonien aufzeigen: zwei auf Galapagos und eine näher am südamerikanischen Kontinent gelegene auf der Isla de la Plata, wo eine kleine Anzahl von Paaren nistet. Die Kombination der Daten von Beschleunigungsmessern mit GPS-Ortsdaten ermöglichte eine operative Klassifizierung des Verhaltens der Galapagosalbatrosse. Alle Vögel aus Galapagos flogen ostwärts zum kontinentalen Schelf und suchten ihre Nahrung südwärts entlang der peruanischen Küste. Vögel von der Isla de la Plata machten häufigere und kürzere Nahrungssuchflüge und nutzten dabei nördlicher gelegene Habitate als die Vögel von Galapagos. Die Vögel von La Plata jagten in Gegenden, die von den Galapagos-Vögeln überflogen wurden, hatten im Schnitt geringere Fluggeschwindigkeiten und legten kürzere Strecken zurück. Insgesamt können die Albatrosse von La Plata mit beständig niedrigeren Beuteerträgen auskommen, haben dafür aber auch einen geringeren Aufwand als die Vögel von Galapagos, die weniger Flüge machen, dafür aber mehr Zeit investieren. Die Galapagos-Vögel sind möglicherweise effektiver bei der Nahrungssuche, aufgrund reichhaltigerer oder profitablerer Nahrungsquellen in diesen hochproduktiven Regionen. Die Vögel der beiden Galapagos-Kolonien flogen zur Nahrungssuche zu ähnlichen Zielen, welche sich mit Regionen überschnitten, die in den Vorjahren aufgrund von Kleinfischerei ein lokal begrenztes Mortalitätsrisiko aufwiesen. Diese über das Brutgebiet der Art ausgedehnte Studie belegt die abweichende Verteilung der La Plata-Albatrosse bei der Nahrungssuche und den potenziellen Erhaltungswert dieser kleinen Kolonie für die Aufrechterhaltung räumlicher Diversität und der Plastizität des Verhaltens.

\section{Introduction}

Studies of central place foragers have made key contributions to our understanding of foraging biology, because the constraints and predicted optima can often be identified clearly (Pyke 1984). The spatial structure of foraging patches presents one such constraint, and patch quality presents another (MacArthur and Pianka 1966). Albatrosses forage in a heterogeneous habitat that includes both sources of variation. A long/short trip distinction demonstrates an apparent trade-off between accessing high-quality patches that improve parental condition and minimizing trip duration when feeding small chicks (Weimerskirch et al. 1994; Fernández et al. 2001). Trips to sites close to breeding colonies can yield poor returns on time invested as more readily available resources are depleted more quickly (Ashmole 1963). As such, the distance travelled is often positively correlated with colony size (Diamond 1978). However, short foraging trips by breeding albatrosses are required when small chicks need frequent meals (Weimerskirch and Lys 2000). On trips encompassing a larger search range, the rate of resource harvest might compensate for longer distances travelled, because higher-quality patches are reached (Weimerskirch et al. 1994). Older chicks' ability to tolerate infrequent meals emancipates the parents from local fishing areas. During long trips, the parents' physiological condition and therefore future reproductive potential improves compared to their reduced physical condition following short trips (Weimerskirch et al. 1993; Fernández et al. 2001; Phalan et al. 2007; Phillips et al. 2009).

In the case of Waved Albatrosses (Phoebastria irrorata Salvin 1883) breeding at Punta Cevallos, Isla Española in the Galápagos Islands, one principal foraging site exists during the breeding season: the Peruvian upwelling, approximately $1,350 \mathrm{~km}$ to the southeast. Parents from Punta Cevallos with eggs and older chicks forage there, but parents constrained by the needs of young chicks forage primarily on the Galápagos platform northwest of Isla Española (Fernández et al. 2001; Awkerman et al. 2005). Albatrosses are also affected by variable prey availability (Rechten 1985; Weimerskirch et al. 2001; Pinaud et al. 2005), such that spatially heterogeneous effects on vital rates could influence population growth and viability. Waved Albatrosses were recently recognized as a Critically Endangered species (IUCN 2012). Their activity in the high-quality, distant patch in the Peruvian upwelling is a central component of their conservation status: the area where parents spend most of their time during incubation and the rearing of large chicks (Anderson et al. 2003) is where adults have been captured in a local artisanal fishery (Awkerman et al. 2006; Jiménez-Uzcátegui et al. 2006).

Insights gained from consideration of the patch structure and foraging distribution of this colonial breeder have an additional implication for conservation. Waved Albatrosses breed at only two sites. The large majority of the population (>15,475 birds; Anderson 2008) breeds on Isla Española in two colonies: Punta Cevallos and Punta Suarez. The remainder of the population (10 20 pairs; Anderson and Cruz 1998) nests on Isla de la Plata, close to the South American mainland and only approximately $850 \mathrm{~km}$ from 
the Peruvian upwelling. The fact that the species has essentially a single point population, on Española, factored heavily in the recent reclassification to a more threatened conservation status (IUCN 2012), and assessing the potential of the small La Plata population as a breeding colony is a proposed conservation action (Waved Albatross Plan of Action, AC6 Document 29; http://www.acap. aq/english/english/advisory-committee/ac6/ac6-meetingdocuments) in light of evidence that the breeding population on Española has declined since 1994 (Anderson 2008). Here, we document the foraging behaviour of the La Plata population for the first time, recording foraging trips using GPS loggers with integral accelerometers. Recognizing that the foraging range of Galápagos birds exposes them to significant fishery mortality, we evaluate how the foraging sites and behaviour of La Plata birds may affect the potential of that colony as a source population for this critically endangered bird.

From an optimization perspective, birds on La Plata may have the same destination on long trips as Galápagos birds do: the Peruvian upwelling. If so, they should have a shorter commute to the Peruvian upwelling, probably increasing their overall harvest rate and, presumably, improving reproductive success compared to Española birds through an indirect competitive advantage. Alternatively, a perspective based on central place foraging theory predicts that the shorter commute of the less numerous La Plata birds should be associated with less stringent requirements for maintaining body condition while in food patches. In this case, La Plata birds may be able to exploit lower-quality patches near La Plata (and closer than the Peruvian upwelling) that Galápagos birds cannot exploit profitably and thus avoid density-dependent competition with the much larger Galápagos population. Shorter, frequent trips consistent with this second hypothesis would not necessarily yield a higher harvest rate if the behaviour of La Plata birds results in, effectively, an approach to an ideal free distribution (Fretwell and Lucas 1970). Closer foraging trips could also reduce mortality risks linked to the upwelling area, increasing the viability of La Plata as a growing population.

Wind speed and direction also shape the distribution (Davies et al. 2010) and foraging patterns (Wakefield et al. 2009) of procellariiforms. Although Waved Albatrosses encounter some of the lowest wind speeds of any seabird (Suryan et al. 2008), any contrast in the wind environment over the routes from colonies to the upwelling could confound predictions based on distance alone. Differential energy expenditure as a result of suboptimal wind patterns and/or orientation to foraging areas could also affect reproductive success.

Here, we present the first tracking data from birds breeding at Punta Suárez, Isla Española and at Isla de la Plata, and compare them with new data from birds from Punta Cevallos. Accelerometer data define the orientations and motions of the animals and indicate movement patterns and differential energy expenditure (they are correlated with heart rate and oxygen consumption; Wilson et al. 2006; Halsey et al. 2008, 2009; Shepard et al. 2008; Gleiss et al. 2011). We evaluate the effects of wind dynamics, behaviour, and habitat on Waved Albatross foraging trip characteristics to test the predictions of hypothesized travel costs and resource availability between breeding birds originating at La Plata versus those from the Galápagos Islands to determine whether optimizing resource acquisition or minimizing travelling costs and competition influence foraging distribution.

\section{Methods}

Equipment deployment

We tracked the movements of breeding birds throughout the 2008 season at two sites on Isla Española in the Galápagos Islands, Punta Cevallos (PC; $1.389^{\circ} \mathrm{S}$, $89.621^{\circ} \mathrm{W}$ ) and Punta Suárez (PS; $1.373^{\circ} \mathrm{S}, 89.740^{\circ} \mathrm{W}$ ), and from Isla de la Plata $\left(\mathrm{LP} ; 1.278^{\circ} \mathrm{S}, 81.082^{\circ} \mathrm{W}\right)$. We used GPS loggers designed by E-obs GmbH (Munich, Germany), each of which had an integral accelerometer and weighed $76 \mathrm{~g}$. The unit mass was $1.73 .0 \%$ of the weight of a representative sample of birds. Units were programmed to record GPS locations every $90 \mathrm{~min}$, and biaxial acceleration data (ACC) in bursts of 60 measurements every $15 \mathrm{~min}$ on two axes, $X$ and $Y$, representing the pitch and roll of the bird. Physical measurements of flight dynamics allowed behavioural classification as well as a comparison of the colonies that might indicate differential energy expenditure. Units were secured with cable ties to bundles of mantle feathers wrapped with Tesa ${ }^{\circledR}$ tape. Equipped birds were incubating at the time of deployment. Birds from Española were within approximately 3 weeks of each other in egg-laying, given the high synchrony of breeding there (Harris 1973; Anderson 2008). Breeding phases on Isla de la Plata coincided with those of Española birds, with hatching occurring in early July. Data from the units were downloaded remotely via UHF radio link to a base station installed at each colony. A base station consisted of a UHF antenna, a receiver with flash memory, and two 6-V batteries. Data were uploaded from each unit to the base station whenever equipped birds were within $100 \mathrm{~m}$ of the station, allowing data collection for extended periods of time. Tags were deployed on 31 May 2008 at PS, 23 June 2008 at PC, and 724 June 2008 at LP. We recovered the base station's data six times between tag deployment and 29 Nov 2008 at the Española colonies, and five times until 6 November 2008 at LP. 
Maps of albatross locations were created with Google Earth, incorporating General Bathymetric Chart of the Oceans (GEBCO) gridded bathymetry data at 30 arc-second resolution (IOC et al. 2009). We acquired data on wind speed and wind vector data from NCEP/DOE Reanalysis II from NOAA's Earth System Research Laboratory Physical Sciences Division (http://www.esrl.noaa.gov/psd/). Chlorophyll $a$ values were from MODIS Aqua data, available at $4 \mathrm{~km}$ resolution from the Physical Oceanography Data Active Archive Center (PODAAC; poet.jpl.nasa.gov).

Data analysis, model selection, multi-model inference

To classify the behaviour at each location, we calculated the minimum, maximum, mean, range, and standard deviation for the burst of pitch and roll activity data collected for the 15-min period that coincided with each GPS location. We further limited data for behavioural analyses in response to Waved Albatrosses' tendency to raft on the ocean near the colony between foraging trips. To eliminate these non-foraging excursions, we counted any foray beyond $10 \mathrm{~km}$ from its nest as a trip. Data analyses were performed in the R software environment ( $\mathrm{R}$ Development Core Team 2011). Kruskal Wallis tests compared colony trip duration, distance, chlorophyll $a$ values, wind speed, and flight speed. A $k$-means partitioning cluster analysis (a hierarchical clustering method) in the package "cluster" delimited behaviour categories using the accelerometer (range and standard deviation of both the $X$ and $Y$ axes) and GPS data (hour of day, speed, and change in bearing between previous and subsequent points, ranging from 0 180). We used the package "CircStats" to calculate the mean bearing and other circular statistics. The package "ncdf" facilitated the acquisition of netCDF files of wind speed and vector. We used the closest zonal and meridional wind speeds at $10 \mathrm{~m}$ height averaged over 6-h periods to calculate wind speed and direction. The closest chlorophyll $a$ values, indicative of habitat productivity, were spatially linked to each GPS location.

We used generalized additive models with a gamma distribution and a log-link function implemented in the package "mgcv" to examine the associations between cumulative distances travelled and trip characteristics to determine how trips of varying lengths differed. Cumulative distance was positively correlated with duration of trip, indicating both energetic investment and distances of profitable foraging patches. Specifically, we constructed a set of 22 models reflecting biologically plausible hypotheses explaining differences in trips by La Plata birds with regard to movement, wind characteristics, or other factors compared to trips by birds from the Española colonies. Dependent variables were modelled as functions of either single, additive, or interactive combinations of the day the trip began (DAY), the bearing between the colony and most distant location (DESTIN), and the wind speed on the return trip, assuming that unfavorable tailwinds might delay the initiation of the return commute (INWIND). Lastly, individual bird identity (INDIV) was included as a random effect in all models to account for the fact that individual birds were tracked over multiple trips. DAY was included based on a priori knowledge of trip length variation in response to breeding phase, which is fairly synchronous (Anderson et al. 2003). DESTIN was used as a small-scale proxy for energetic power needed and represented the angle at which the bird was flying relative to fairly consistent easterly winds during breeding, presuming that trips with more frequent headwinds would be more energetically costly. Birds might take advantage of greater wind speeds to facilitate their return trip and delay their return trip until wind conditions are favourable, hence our inclusion of INWIND in some models.

We used an information-theoretic approach for model selection and inference (Burnham and Anderson 2002; Anderson 2008). Models were ranked using Akaike's information criterion corrected for small sample sizes (AICc), where the model with the lowest AICc was considered the best model in the given set (Burnham and Anderson 2002). For each model in the candidate model set, we report the AICc difference $(\triangle \mathrm{AICc}), \log$ likelihood, Akaike weight (i.e., model probability), the deviance explained, and the estimated degrees of freedom (EDF).

\section{Results}

\section{Trip description}

Accelerometer and GPS data were collected from sixteen birds (seven from PS, four from PC, and five from LP) from 27 May to 2 November (PS range $=27$ May 3 August, median $=3$ July; PC range $=21$ June 20 September, median $=29$ July; $\quad$ LP range $=25$ June 2 November, median $=27$ August). The cumulative tracking period for individual birds ranged from 1 to 130 days (median $=45.5$ days). Because tracking duration differed, we standardized trip frequency according to the number of birds tracked and the duration of tracking (birddays) to allow comparisons among colonies. A total of 290 trips exceeded a distance of $10 \mathrm{~km}$ from the nest (193 from LP, 50 from PC, and 47 from PS). The frequency distribution of the cumulative distance for each trip travelled was bimodal, with no trips with distances of $553783 \mathrm{~km}$ observed (Fig. 1). We therefore used a criterion of $600 \mathrm{~km}$ cumulative distance to distinguish short from long trips. Isla de la Plata birds made more trips in total (LP 
median $=27$ trips/bird, 0.15 trips per birdday tracked, PC median $=11.5,0.14$ trips per birdday tracked; PS median $=7,0.004$ trips per birdday tracked; Table 1) as a result of spending more time on short trips (LP median proportion of trips $<600 \mathrm{~km}=1$, PC median proportion $=0.84$, PS median proportion $=0.75 ; \chi^{2}=6.34$, $p=0.04$ ) and traveling shorter distances in general (LP median $=66.90 \mathrm{~km} \mathrm{~d}^{-1}, \quad$ PC median $=168.55 \mathrm{~km} \mathrm{~d}^{-1}$, PS median $=161.06 \mathrm{~km} \mathrm{~d}^{-1} ; \chi^{2}=7.62, p=0.02$ ) than did birds from Española colonies. The cumulative distance for all trips by LP birds was less (median $=73.53$ per trip, range $=11.112,335.63 \mathrm{~km}$ ) than those for all trips by PC birds $\quad($ median $=226.20, \quad$ range $=12.335,299.21 \mathrm{~km})$ or by PS birds $\quad($ median $=192.15, \quad$ range $=38.22$ $5,388.18 \mathrm{~km} ; \chi^{2}=47.93, p<0.01$; Fig. 1). Maximum distance from the colony was also less for LP birds than for PC or PS birds (LP median $=34.11 \mathrm{~km}$, range $=$ $10.01887 .21 \mathrm{~km} ;$ PC median $=72.12$, range $=10.57$ $1,807.53 \mathrm{~km} ; \quad$ PS median $=63.61, \quad$ range $=17.45$ $\left.1,496.11 ; \chi^{2}=46.51, p<0.01\right)$.

The destination for all long trips was the Peruvian coastal area near the upwelling. Considering only birds on long trips, those from PS and PC travelled farther south in the upwelling than did birds from LP (Fig. 2). The median most southerly latitude value for long trips by LP birds was only $4.86^{\circ} \mathrm{S}$ (range $=4.628 .88^{\circ} \mathrm{S}$ ), while the median value for the $\mathrm{PC}$ birds making long trips was $7.18^{\circ} \mathrm{S}$ $\left(\right.$ range $\left.=1.38^{\circ} 12.77^{\circ} \mathrm{S}\right)$ and $7.98^{\circ} \mathrm{S} \quad\left(\right.$ range $=3.18^{\circ}$ $9.07^{\circ} \mathrm{S}$ ) for the PS birds on long trips. The chlorophyll $a$ values were lower at locations of LP birds (median $=0.47 \mathrm{mg} \mathrm{m}^{-3}, \quad 1 \mathrm{st} \quad$ quartile $=0.30$, 3rd quartile $=0.67$ ) compared to $\mathrm{PC}$ (median $=0.41 \mathrm{mg} \mathrm{m}^{-3}, 1 \mathrm{st}$ quartile $=0.30, \quad 3$ rd quartile $=1.27)$ and PS birds (median $=0.44 \mathrm{mg} \mathrm{m}^{-3}$, 1st quartile $=0.25$, 3rd quartile $=1.32 ; \chi^{2}=10.94, p<0.01$; Fig. 3 ).

\section{Trip behaviour}

Four clusters best categorized variance in movement characteristics. $k$-means cluster analysis partitioned GPS locations into four categories that were better distinguished by the inclusion of acceleration data in the movement variables than by previous categorization of behaviours based solely on GPS information (cf. Awkerman et al. 2005; Table 2). A cross-validation discriminant function analysis indicated a high proportion of predictive precision $(0.94,1.00,0.97$, and 0.89 for each of the four clusters; 0.97 overall). Putative flight behaviour was identified by an average speed of $16 \mathrm{~km} \mathrm{~h}^{-1}$ that occurred most frequently during the day and during the commuting portion of the trip (Table 3 ). We classified a second category, characterized by moderate speed and more variation in pitch and roll, as "foraging". These points were located primarily along the productive South American coast or within Galápagos (Fig. 4), and were distinguished by much greater ranges in pitch and roll (Table 3). The third and fourth clusters were similar in terms of the slow speed travelled to the subsequent location and the minimal range of motion on both accelerometer axes (Table 3), and we interpret these as floating behaviour. Locations within these two floating clusters differed in the time of day at which they were recorded, one primarily during the middle of the night (median time $=23: 30$ ) and the other around midday (median time $=12: 00$ ). The night floating points had lower ranges of pitch and roll values, with several consecutive points following a consistent trajectory, which is suggestive of sleeping behaviour in which currents
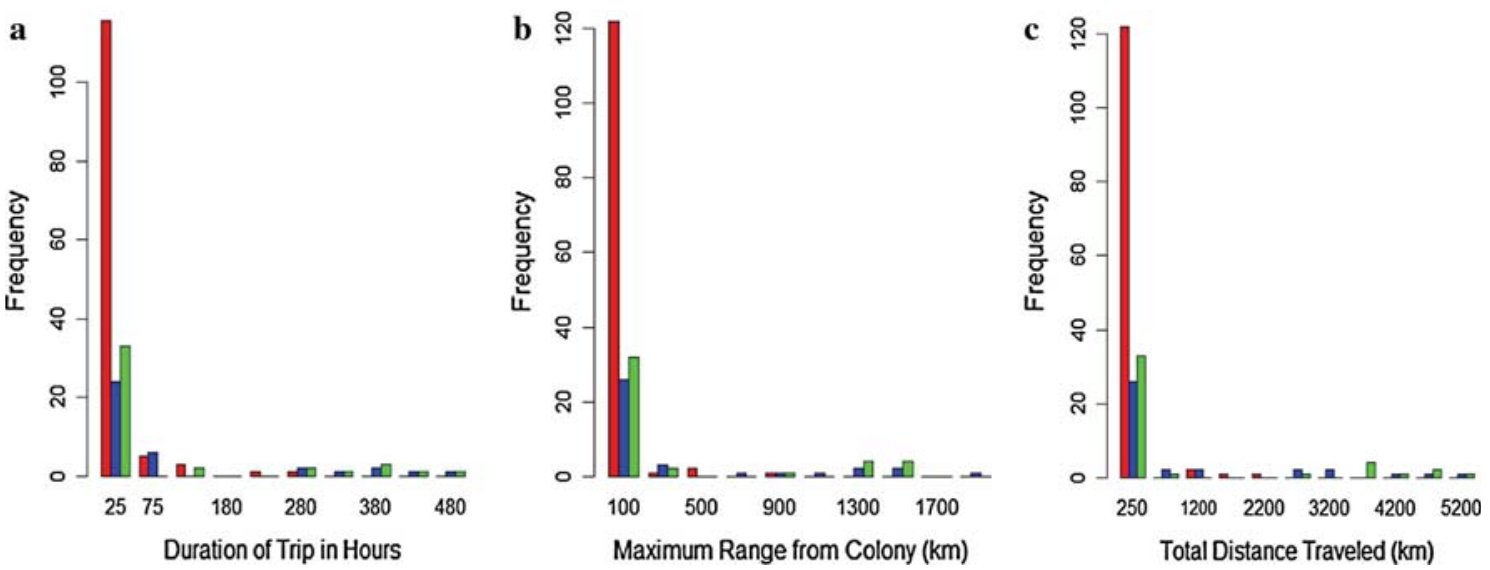

Fig. 1 Distributions of trip duration (a), maximum range (b), and cumulative distance (c) travelled for each colony of Waved Albatrosses (red LP, blue PC, green PS) 
Table 1 Characteristics of the trips taken by sixteen Waved Albatrosses tracked from three breeding colonies in 2008

\begin{tabular}{|c|c|c|c|c|c|c|c|c|c|c|c|c|}
\hline $\begin{array}{l}\text { Bird } \\
\text { ID }\end{array}$ & Colony & $\begin{array}{l}\text { First } \\
\text { day }\end{array}$ & $\begin{array}{l}\text { Last } \\
\text { day }\end{array}$ & $\begin{array}{l}\text { Days } \\
(n)\end{array}$ & $\begin{array}{l}\text { Trips } \\
(n)\end{array}$ & $\begin{array}{l}\text { Short } \\
\text { trips } \\
(n)\end{array}$ & $\begin{array}{l}\text { Long } \\
\text { trips } \\
(n)\end{array}$ & $\begin{array}{l}\text { Median trip } \\
\text { length } \\
\text { (short) }\end{array}$ & $\begin{array}{l}\text { Median trip } \\
\text { length } \\
\text { (long) }\end{array}$ & $\begin{array}{l}\text { Min. } \\
\text { distance } \\
\text { from colony }\end{array}$ & $\begin{array}{l}\text { Max. } \\
\text { distance } \\
\text { from colony }\end{array}$ & $\begin{array}{l}\text { Cumul. } \\
\text { distance } \\
\text { travelled }\end{array}$ \\
\hline 131 & PS & 2 Jun 08 & $16 \mathrm{Jul} 08$ & 44 & 8 & 6 & 2 & 198.09 & $2,269.03$ & 49.23 & $1,340.96$ & $6,025.39$ \\
\hline 132 & $\mathrm{PC}$ & 29 Jun 08 & $15 \mathrm{Sep} 08$ & 78 & 14 & 11 & 3 & 241.00 & $4,083.07$ & 11.72 & $1,807.53$ & $15,152.25$ \\
\hline 134 & PS & 6 Jun 08 & 7 Aug 08 & 62 & 18 & 16 & 2 & 108.02 & $3,961.66$ & 21.73 & $1,496.11$ & $9,985.58$ \\
\hline 136 & $\mathrm{PC}$ & $2 \mathrm{Jul} 08$ & 28 Sep 08 & 88 & 24 & 19 & 5 & 182.91 & $2,850.69$ & 10.58 & $1,298.44$ & $15,958.86$ \\
\hline 141 & $\mathrm{PC}$ & 24 Jun 08 & $1 \mathrm{Jul} 08$ & 7 & 3 & 3 & 0 & 81.67 & & 10.57 & 69.01 & 348.28 \\
\hline 147 & PS & 12 Jun 08 & $3 \mathrm{Jul} 08$ & 21 & 1 & 0 & 1 & & $4,153.42$ & $1,474.02$ & $1,474.02$ & $4,153.42$ \\
\hline 150 & PS & 2 Jun 08 & 3 Jun 08 & 1 & 1 & 1 & 0 & 214.44 & & 93.57 & 93.57 & 214.44 \\
\hline 152 & PS & 31 May 08 & $16 \mathrm{Jul} 08$ & 46 & 9 & 8 & 1 & 110.52 & $3,647.59$ & 19.28 & $1,340.56$ & $4,697.28$ \\
\hline 153 & LP & $14 \mathrm{Jul} 08$ & $28 \mathrm{Sep} 08$ & 76 & 21 & 19 & 2 & 82.32 & $1,675.44$ & 10.61 & 887.21 & $5,378.48$ \\
\hline 154 & LP & $12 \mathrm{Jul} 08$ & 9 Sep 08 & 59 & 27 & 27 & 0 & 51.56 & & 10.28 & 159.14 & $2,496.06$ \\
\hline 156 & LP & 19 Jun 08 & 12 Oct 08 & 115 & 72 & 72 & 0 & 42.75 & & 10.01 & $1,028.62$ & $5,326.3$ \\
\hline 157 & $\mathrm{PC}$ & 30 Jun 08 & 2 Aug 08 & 33 & 9 & 8 & 1 & 162.83 & $3,457.97$ & 13.34 & $1,413.83$ & $5,139.46$ \\
\hline 158 & PS & 1 Jun 08 & $10 \mathrm{Jul} 08$ & 39 & 3 & 2 & 1 & 113.31 & $4,528.37$ & 17.45 & $1,435.37$ & 4,755 \\
\hline 159 & LP & 29 Jun 08 & 6 Nov 08 & 130 & 66 & 64 & 2 & 90.09 & $1,317.87$ & 11.1 & 414.53 & $10,445.03$ \\
\hline 160 & LP & $16 \mathrm{Jul} 08$ & 24 Jul 08 & 8 & 7 & 7 & 0 & 88.20 & & 16.2 & 62.03 & 535.23 \\
\hline 161 & PS & 17 Jun 08 & 1 Aug 08 & 45 & 7 & 4 & 3 & 258.18 & $4,584.77$ & 48.97 & $1,245.73$ & $13,983.94$ \\
\hline
\end{tabular}

Distances represent the farthest point from the colony during all forays (trips $(n)$ ) exceeding $10 \mathrm{~km}$ from the point of deployment. $L P$ indicates that the bird's colony of origin was Isla de La Plata off the coast of Ecuador; birds from $P C$ originated from Punta Cevallos, and $P S$ birds started at Punta Suarez on Espanola Island, Galápagos, Ecuador. Distances indicated are in km

determined movement. The diurnal floating points, with a greater average speed and range of motion, indicated more activity during this resting period. Flight and foraging points were mostly diurnal, with more frequent morning activity (flight median time $=09: 15$; foraging median time $=$ 08:45). Birds from the three colonies spent similar proportions of time engaged in each of the four behaviours during long trips.

\section{Cumulative trip distance}

Of the 290 trips, we omitted 84 of the shorter trips from the following analyses because of insufficient data to compare different portions of the trip or specific behaviours. The topranked model in our analysis included an interaction of the day on which the trip began (DAY) and the bearing to destination (DESTIN) as well as additive effects of the proportion of time spent in flight (PROPFLIGHT; Table 4). The top-ranked model accounted for all of the model weight in the model set (Akaike weight $=1.00$; Table 4). The interaction between initiation of trip and destination in the top model identified primarily the stage-dependent dual strategy of Española birds, which often travelled in different directions for short brooding trips within Galápagos, as compared to longer incubation trips taken in a southeasterly direction toward the upwelling (Fig. 5). La Plata birds did not demonstrate a dichotomous foraging strategy in terms of departure direction or trip distance.
Flight activity

Wind speed during activity classified as flight was similar for PC $\left(\right.$ median $=6.11 \mathrm{~km} \mathrm{~h}^{-1}$, range $\left.=0.4211 .63 \mathrm{~km} \mathrm{~h}^{-1}\right)$ and $\quad$ LP $\quad\left(\right.$ median $=6.04 \mathrm{~km} \mathrm{~h}^{-1}, \quad$ range $=0.7011 .17$ $\mathrm{km} \mathrm{h}^{-1}$ ) birds, with PS birds encountering slightly weaker winds (median $=5.05 \mathrm{~km} \mathrm{~h}^{-1}$, range $=0.1410 .78 \mathrm{~km} \mathrm{~h}^{-1}$; $\left.\chi^{2}=88.16, p<0.01\right)$. LP birds encountered more headwinds from the left side and tailwinds from the right, relative to body orientation, while PC and PS birds encountered winds from a broad range during the clockwise progression of the trips, with slightly higher frequencies of tailwinds (Fig. 6; see the Electronic supplementary information). However, flight speeds were markedly faster for Española birds than for LP birds (LP median speed $=8.78 \mathrm{~km} \mathrm{~h}^{-1}$, range $=0.0455 .29 \mathrm{~km} \mathrm{~h}^{-1}$, $n=663$; PC median speed $=20.09 \mathrm{~km} \mathrm{~h}^{-1}$, range $=0.11$ $59.60 \mathrm{~km} \mathrm{~h}^{-1}, n=759$; PS median speed $=18.15 \mathrm{~km} \mathrm{~h}^{-1}$, range $\left.=0.0861 .19 \mathrm{~km} \mathrm{~h}^{-1}, n=903\right)$. Birds reached their greatest flight speeds with a tailwind (Fig. 7).

\section{Discussion}

Waved Albatrosses breeding at La Plata demonstrated smaller foraging ranges and lower flight speeds, indicative of a less distinct commuting portion of foraging trips, as compared to birds from Galápagos colonies. We interpret these results as consistent with a central place foraging 

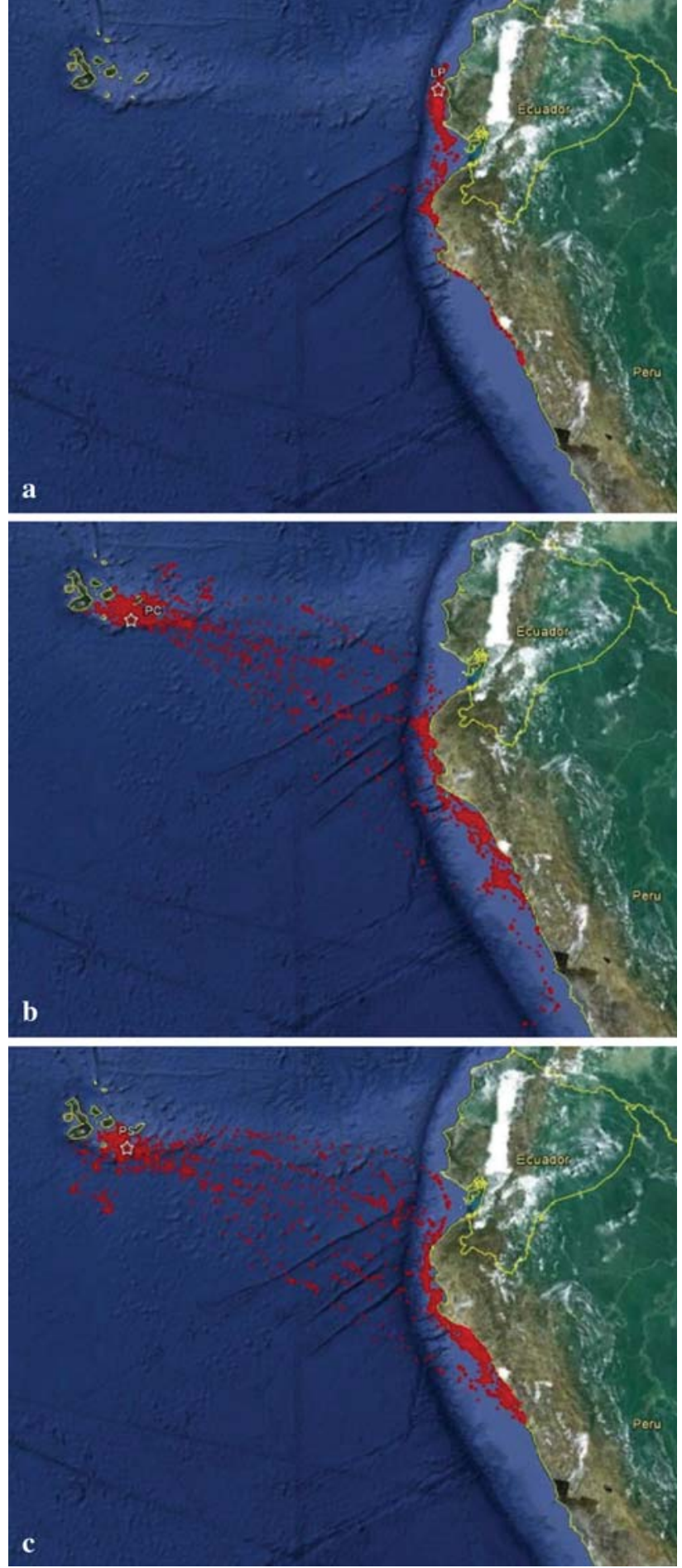

Fig. 2 All GPS locations recorded more than $10 \mathrm{~km}$ from the initial deployment location at a Isla de la Plata, b Punta Cevallos and c Punta Suárez are indicated by red circles, while colony locations are identified with white stars

model which assumes that optimal foraging load is correlated with distance from the colony, with short travel times allowing profitable exploitation of nearby foraging sites that are less productive than the Peruvian upwelling.

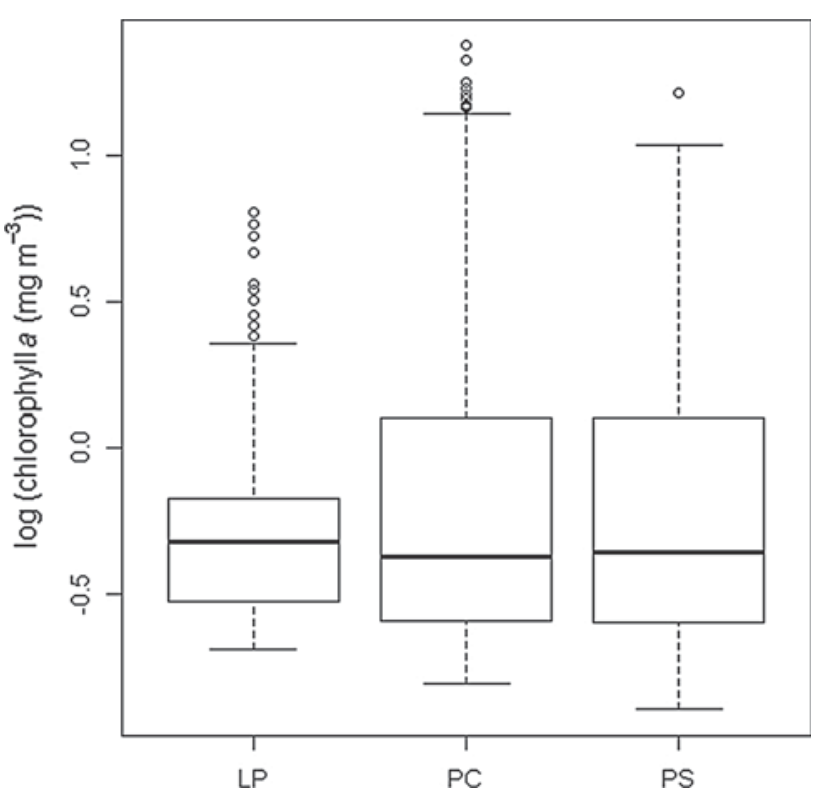

Fig. 3 Chlorophyll $a$ values for GPS locations collected on all trips, presented by breeding colony

Among all of the birds tracked, cumulative distance travelled depended on when the trip began, the proportion of time spent flying, and the direction the bird travelled, distinguishing the longer commutes made in the direction of the mainland while incubating and raising large chicks for Española birds.

In terms of resource acquisition, benefits for LP birds of travelling less and reducing competition are dependent on the quality of their foraging habitat and the density of competitors there compared to those of foraging areas farther south in the upwelling. The circumstances suggest that only the LP birds can take advantage of the areas north of the upwelling, with birds from Española constrained by their longer travel times to forage in the high-reward areas. Rejection of a direct commute to this area by LP birds is consistent with central place foraging theory that predicts search times varying in relation to the return rate associated with the food patch (Orians and Pearson 1979). These birds may be foraging in a more variable environment with generally lower productivity, but they avoid the costs of competing for resources in the more productive environment where Española birds forage. Not accessing the more productive areas of the upwelling that are exploited by multiple seabird species, and thereby securing an indirect competitive advantage, could indicate that sufficient local resources require smaller travelling distances for the smaller population (Diamond 1978). Density-dependent effects of proximal resource depletion would also be minimized, thus reducing the effect of Ashmole's halo (Birt et al. 1987).

The energetic implications of a primarily short trip strategy should be considered in addition to the availability 
Table 2 Comparison of the results of two different approaches to categorizing the behaviours of Waved Albatrosses

\begin{tabular}{llrrrrr}
\hline & & \multicolumn{3}{l}{ Behavioural categorization based on new criteria, including accelerometer data } \\
\cline { 3 - 7 } & & Flight & Nocturnal floating & Diurnal resting & Foraging & Total \\
\hline Behavioural categorization & Flight & $\mathbf{1 , 8 5 5}$ & 285 & 757 & 73 & 2,970 \\
based on previous methods & Float & 116 & $\mathbf{6 9 6}$ & $\mathbf{3 6 2}$ & 28 & 1,202 \\
using only GPS data & Forage & 354 & 1,830 & 1,001 & $\mathbf{5 1}$ & 3,236 \\
(Awkerman et al. 2005) & Total & 2,325 & 2,811 & 2,120 & 152 \\
\hline
\end{tabular}

Each value (aside from those in the "Total" row and column) is the frequency of a particular combination of behavioural categories assigned using the two approaches (for instance, the frequency with which both approaches categorized the behaviour as "flight" was 1,855 )

Bold numbers indicate frequencies where similar categorizations were assigned using both approaches

Table 3 Median values of movement characteristics used in cluster analysis to identify four behaviours from accelerometer data collected from Waved Albatrosses equipped with GPS units in 2008

\begin{tabular}{lrrrr}
\hline $\begin{array}{l}\text { Trip } \\
\text { characteristics }\end{array}$ & \multicolumn{3}{l}{ Behavioural categorization } & \\
\cline { 2 - 5 } & Flight & $\begin{array}{l}\text { Nocturnal } \\
\text { floating }\end{array}$ & $\begin{array}{l}\text { Diurnal } \\
\text { resting }\end{array}$ & Foraging \\
\hline Speed & 15.72 & 1.28 & 2.12 & 3.57 \\
Heading & 67.29 & 60.15 & 65.06 & 51.35 \\
Hour & 9.25 & 23.50 & 12.01 & 8.75 \\
$X$ range & 336.00 & 127.00 & 148.00 & $1,219.50$ \\
$Y$ range & 362.00 & 99.00 & 104.00 & 795.50 \\
$X$ SD & 60.85 & 26.56 & 30.91 & 172.15 \\
$Y$ SD & 67.22 & 21.05 & 21.78 & 130.16 \\
\hline
\end{tabular}

Speed is the speed in $\mathrm{km} \mathrm{h}^{-1}$ to the next location. Heading describes the movement to the subsequent point in either direction as an absolute angle between 0 and $180^{\circ}$. Hour is the proportional local hour (e.g. 23.50 23:30). The range and standard deviation (SD) values are presented for both the $X$ and $Y$ axes (pitch and roll, respectively) for the accelerometer data

of local resources. LP birds flew at lower flight speeds, indicative of shorter sustained flight periods, perhaps due to successful prey location or, in response to encountering less favourable wind dynamics. The triangular route travelled by birds from Española could minimize energetic expenditure by reducing flight into southeasterly headwinds and optimizing efficiency on return trips with a tailwind (Raymond et al. 2010). Española birds reached the greatest flight speeds when travelling with a tailwind, and La Plata birds encountered tailwinds less frequently than Española birds (Fig. 6).

Energy expenditure by LP birds was also presumably greater, given that frequent take-offs associated with foraging are more costly than flight behaviour (Shaffer et al. 2001). Energy-efficient dynamic soaring patterns in albatrosses complicate the energetic interpretation of flight behaviour. Variability in accelerometer data during highspeed portions of foraging trips suggest that finer-resolution accelerometer data might distinguish between flapping and soaring flight behaviour, activities that differ in exertion and the use of available wind energy. Our data indicating active foraging behaviour in the Waved Albatross demonstrated the greatest range of pitch and roll values of all of the behaviours delimited, suggesting that this activity is the most costly for this species (Halsey et al. 2008; Gleiss et al. 2011). Movements in flight resulted in greater fluctuation in both pitch and roll movements than did floating behaviours, but much less than foraging behaviours, consistent with previous studies that have shown that flight is relatively cheap energetically for albatrosses, with heart rates during flight near those maintained at rest (Shaffer et al. 2001).

Waved Albatross movement produces accelerometer data that are more variable than those of terrestrial species on which the same equipment was deployed (Wilson et al. 2008; Holland et al. 2009), resulting in less discrete visual distinctions among behaviours while in the marine environment. Nonetheless, accelerometer data were useful in defining four types of activity that improved upon previous classifications of Waved Albatross behaviour. Previous GPS tracking suggested that Waved Albatrosses are less active at night than during the day. Foraging and flight behaviour in this study were again mainly diurnal, and in fact matinal, while floating behaviour was more appropriately partitioned into slower linear floating at night and bouts of resting on the water during daylight hours. Inclusion of accelerometer data in this study was more informative than previous distinctions based solely on speed and turning angle of the bird (Awkerman et al. 2005; Table 3). Turning angle at the temporal scale used for GPS point acquisition is minimally informative, presumably because most foraging activity happens at a finer temporal resolution than that resolved here. As a result, previous criteria would have classified many points as foraging that are considered floating by our cluster partitioning with the approach used here (Table 3). Our analysis found movement data collected at a finer temporal scale informative, encouraging future studies to incorporate more frequent 


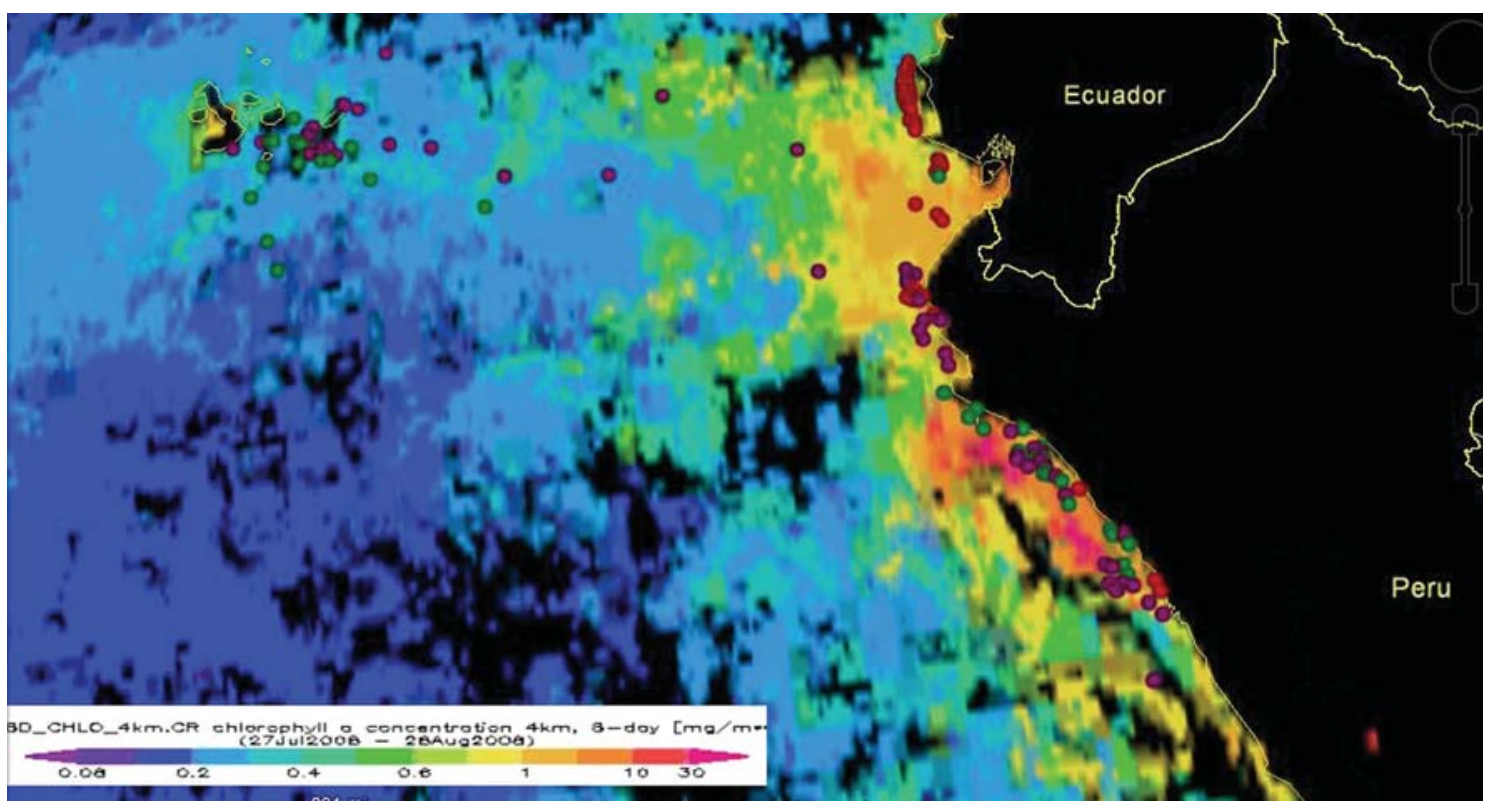

Fig. 4 Chlorophyll $a$ values $\left(\mathrm{mg} \mathrm{m}^{-3}\right)$ in the Waved Albatross foraging range during 27 July 28 August 2008, approximately midway through data collection, as determined from MODIS Aqua data at $4 \mathrm{~km}$ resolution. Marine areas without colour indicate areas where cloud cover prevented data collection. Points represent locations classified as foraging for La Plata (red), Punta Cevallos (purple), and Punta Suarez (green)
Fig. 5 a Bearing to destination from colony and b Julian date on which the trip was initiated relative to the cumulative distance travelled for 206 trips for birds from La Plata (red), Punta Cevallos (blue), and Punta Suarez (green)

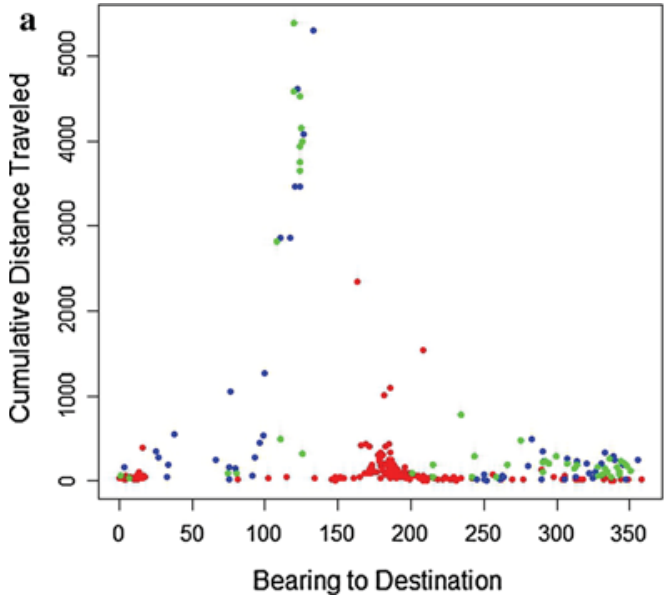

data acquisition for examining foraging behaviour in greater detail.

Discrepancies in the timing of unit deployment among the three colonies might have affected the distribution of trip distances over time, such that additional tracking might have incorporated longer trips later in the season for birds from PC and PS. However, four of the tagged birds from LP were tracked into the later chick-rearing stage, when Waved Albatross parents from PC make longer trips, and we found that LP parents did not lengthen their trip durations or distances. Like any tracking study, small sample sizes limit population-level inferences; however, including both time and individual as factors in models helped to identify any random effects.

The viability of the La Plata population is dependent on the capacity of local resources to support reproductive success if the small population increases in size. Lower extrinsic mortality risk in northerly foraging patches with less bycatch could compensate for apparently lower reproductive success within the La Plata colony, but feral cats on La Plata are a potential source of additional mortality for birds in this colony. Observer programs have identified seabird bycatch near Ecuadorian coasts where La Plata birds forage as well (Mangel et al. 2011), and 
Table 4 Candidate model set and ranking of models examining the relation between cumulative distance travelled and foraging trip characteristics

\begin{tabular}{lrrrrrr}
\hline Model & EDF & \multicolumn{1}{l}{ AICc } & \multicolumn{1}{c}{$\Delta$ AICc } & \multicolumn{1}{c}{$w_{i}$} & Log likelihood & $D^{2}$ \\
\hline DAY $\times$ DESTIN + PROPFLIGHT & 29.510 & $2,587.350$ & 0.000 & 1.000 & $1,257.655$ & 0.808 \\
DAY + PROPFLIGHT + DESTIN & 17.783 & $2,617.019$ & 29.670 & 0.000 & $1,287.732$ & 0.748 \\
PROPFLIGHT + DESTIN & 14.501 & $2,627.813$ & 40.464 & 0.000 & $1,297.056$ & 0.727 \\
DAY + PROPFLIGHT $\times$ DESTIN & 18.382 & $2,646.515$ & 59.165 & 0.000 & $1,301.747$ & 0.715 \\
PROPFLIGHT $\times$ DESTIN & 15.854 & $2,654.261$ & 66.912 & 0.000 & $1,308.677$ & 0.697 \\
DAY + DESTIN & 11.700 & $2,671.525$ & 84.176 & 0.000 & $1,322.158$ & 0.660 \\
DESTIN $\times$ INWIND & 16.624 & $2,671.882$ & 84.533 & 0.000 & $1,316.566$ & 0.676 \\
DAY + DESTIN + INWIND & 12.664 & $2,672.853$ & 85.503 & 0.000 & $1,321.715$ & 0.661 \\
DESTIN & 8.862 & $2,678.336$ & 90.986 & 0.000 & $1,328.757$ & 0.640 \\
DESTIN + INWIND & 9.852 & $2,680.099$ & 92.750 & 0.000 & $1,328.535$ & 0.640 \\
DAY + PROPFLIGHT & 11.367 & $2,717.064$ & 129.714 & 0.000 & $1,345.306$ & 0.585 \\
PROPFLIGHT & 8.942 & $2,735.934$ & 148.584 & 0.000 & $1,357.467$ & 0.540 \\
DAY & 3.832 & $2,865.441$ & 278.091 & 0.000 & $1,427.748$ & 0.189 \\
INWIND & 3.397 & $2,911.542$ & 324.192 & 0.000 & $1,451.256$ & 0.029 \\
\hline M & & & &
\end{tabular}

Models are presented in order of increasing AICc and $\triangle \mathrm{AICc}$ values; also included are the estimated degrees of freedom $(E D F)$, as adjusted for smoothing parameters, Akaike weights $\left(w_{i}\right)$, log likelihood values, and deviance $\left(D^{2}\right)$. Characteristics of the foraging trip included in this model set were bearing to destination (DESTIN), the wind speed on the return portion of the trip (INWIND), the proportion of time the bird spent in flight (PROPFLIGHT), and day on which the trip began (DAY). A random effects term to account for variation at the individual bird level was also included in each model

La Plata

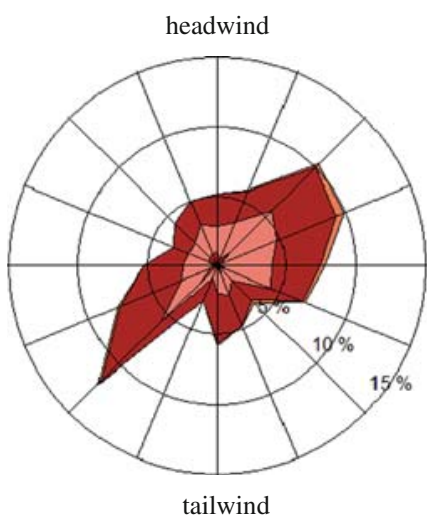

Pta Cevallos

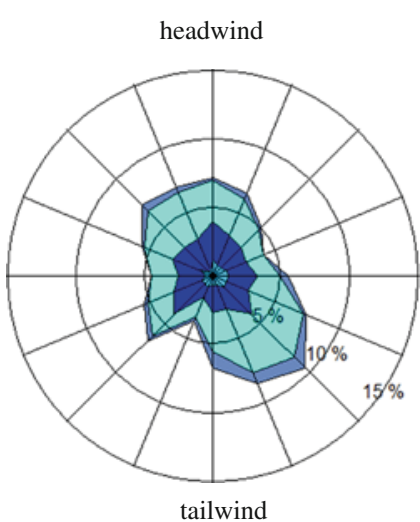

Pta Suarez

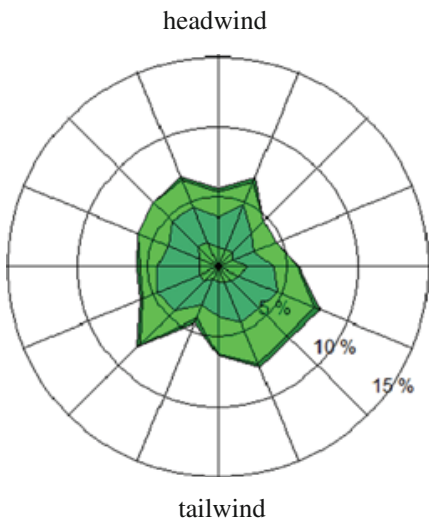

Fig. 6 Rose diagrams of wind direction and speeds encountered by Waved Albatrosses from three different colonies during flight on trips recorded in 2008 (LP red, PC blue, PS green). Wind direction is presented in proportions relative to the direction in which the bird is travelling and further classified by wind speeds, which are layered by colour in decreasing increments of $3 \mathrm{~m} \mathrm{~s}^{-1}$ additional information on bycatch throughout the Waved Albatross range is needed to compare mortality rates in an appropriate context. Assuming higher adult survival, the potential contribution of the La Plata subpopulation to overall population growth could mitigate the extinction risk of a primarily point source population over greater time scales.
Acknowledgments We thank the Galápagos National Park Service and the Ministry of the Environment of Ecuador for permission to work in the parks; Machalilla National Park, the Charles Darwin Research Station, Charles Darwin Foundation, and TAME Airlines for logistical support; Mathias Berger of Movebank for the albatross animation; Franz Kümmeth for technical support; and anonymous reviewers for comments on an earlier draft. We also thank Christian Sevilla and rangers for assistance with albatross monitoring. This 


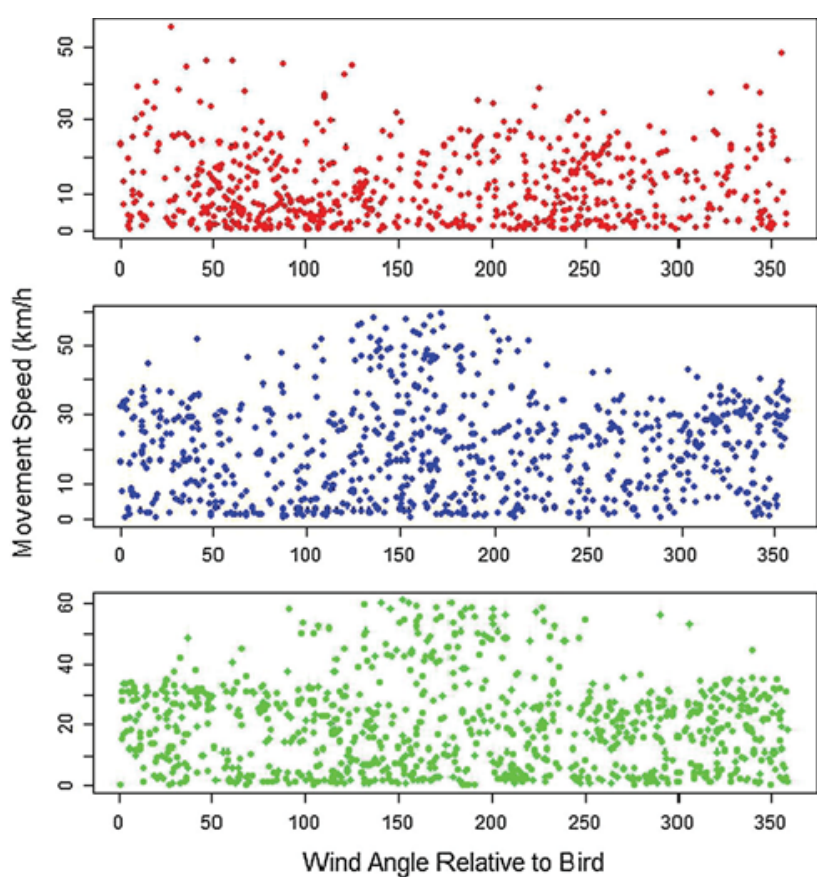

Fig. 7 Speeds of tracked birds at GPS locations classified as flight in relation to the direction that the bird is oriented relative to the wind. Birds were tracked from La Plata (red), Punta Cevallos (blue), and Punta Suarez (green). Tailwinds are represented as $180^{\circ}$ relative to body orientation, and headwinds are represented by both the $0^{\circ}$ and $360^{\circ}$ ends of the $X$ axis

material is based upon work supported by National Science Foun dation grant no. DEB 0842199 to DJA, Max Planck Society and State of Baden Wuerttemberg Innovation funding to MW, and a Colorado State University International Programs grant to KPH.

\section{References}

Anderson DR (2008) Model based inference in the life sciences: a primer on evidence. Springer, New York

Anderson DJ, Cruz F (1998) Biology and management of the Waved Albatross at the Galápagos Islands. In: Robertson G, Gales R (eds) Albatross biology and conservation. Surrey Beatty \& Sons, Chipping Norton, pp 105109

Anderson DJ, Huyvaert KP, Wood DR, Gillikin CL, Frost BJ, Mourtisen H (2003) At sea distribution of Waved Albatrosses and the Galápagos Marine Reserve. Biol Conserv 110:367 373

Ashmole NP (1963) The regulation of numbers of tropical oceanic birds. Ibis 103:458 473

Awkerman JA, Fukuda A, Higuchi H, Anderson DJ (2005) Foraging activity and submesoscale habitat use of Waved Albatrosses Phoebastria irrorata during the chick brooding period. Mar Ecol Prog Ser 291:289 300

Awkerman JA, Huyvaert KP, Mangel J, Alfaro Shigueto J, Anderson DJ (2006) Incidental and intentional catch threatens Galápagos Waved Albatross. Biol Conserv 133:483 489

Birt VL, Birt TP, Goulet D, Cairns DK, Montevecchi WA (1987) Ashmole's halo: direct evidence for prey depletion by a seabird. Mar Ecol Prog Ser 40:205 208
Burnham KP, Anderson DR (2002) Model selection and multimodel inference: a practical information theoretic approach, 2nd edn. Springer, New York

Davies RG, Irlich UM, Chown SL, Gaston KJ (2010) Ambient, productive and wind energy, and ocean extent predict global species richness of procellariiform seabirds. Global Ecol Bioge ogr 19:98 110

Diamond AW (1978) Feeding strategies and population size in tropical seabirds. Am Nat 112:215 221

Fernández P, Anderson DJ, Sievert PR, Huyvaert KP (2001) Foraging destinations of three low latitude albatross (Phoebastria) spe cies. J Zool 254:391 404

Fretwell SD, Lucas HL (1970) On territorial behaviour and other factors influencing habitat distribution in birds I. Theoretical development. Acta Biotheor 19:16 36

Gleiss AC, Wilson RP, Shepard ELC (2011) Making overall dynamic body acceleration work: on the theory of acceleration as a proxy for energy expenditure. Methods Ecol Evol 2:23 33. doi:10. 1111/j.2041 210X.2010.00057.x

Halsey LG, Shepard ELC, Hulston CJ, Venables MC, White CR, Jeukendrup AE, Wilson RP (2008) Acceleration versus heart rate for estimating energy expenditure and speed during locomotion in animals: tests with an easy model species, Homo sapiens. Zoology 111:231 241

Halsey LG, Shepard ELC, Quintana F, Laich AG, Green JA, Wilson RP (2009) The relationship between oxygen consumption and body acceleration in a range of species. Comp Biochem Physiol Pt A 152:197 202

Harris MP (1973) The biology of the waved albatross Diomedea irrorata of Hood Island, Galápagos. Ibis 115:483 510

Holland RA, Wikelski M, Kümmeth F, Bosque C (2009) The secret life of oilbirds: new insights into the movement ecology of a unique avian frugivore. PLoS One 4(12):e8264. doi:10.1371/ journal.pone.0008264

IOC, IHO, BODC (2009) Centenary Edition of the GEBCO Digital Atlas (published on CD ROM on behalf of the Intergovernmen tal Oceanographic Commission and the International Hydro graphic Organization as part of the General Bathymetric Chart of the Oceans). British Oceanographic Data Centre, Liverpool

IUCN (2012) IUCN Red List of Threatened Species. www. iucnredlist.org. Last accessed 31 Jan 2013

Jiménez Uzcátegui G, Mangel J, Alfaro Shigueto J, Anderson DJ (2006) Fishery bycatch of the waved albatros $P$. irrorata, a need for implementation of agreements. Galápagos Res 64:7 9

MacArthur RH, Pianka ER (1966) On optimal use of a patchy environment. Am Nat 100:603 609

Mangel JC, Alfaro Shigueto J, Baquero A, Darquea J, Godley BJ, Norris JH (2011) Seabird bycatch by small scale fisheries in Ecuador and Peru. SBWG 4 Doc 24. In: 6th Meet Advis Committee Agreement on the Conservation of Albatrosses and Petrels, Guayyaquil, Equador, 27 Aug 2 Sept 2011

Orians GH, Pearson NE (1979) On the theory of central place foraging. In: Horn DJ, Mitchell RD, Stairs GR (eds) Analyses of ecological systems. Ohio State University Press, Columbus, pp 154177

Phalan B, Phillips RA, Silk JRD, Afanasyev V, Fukuda A, Fox J, Catry P, Higuchi H, Croxall JP (2007) Foraging behaviour of four albatross species by night and day. Mar Ecol Prog Ser 340:271 286

Phillips RA, Wakefield ED, Croxall JP, Fukuda A, Higuchi H (2009) Albatross foraging behaviour: no evidence for dual foraging, and limited support for anticipatory regulation of provisioning at South Georgia. Mar Ecol Prog Ser 391:279 292

Pinaud D, Cherel Y, Weimerskirch H (2005) Effect of environmental variability on habitat selection, diet, provisioning behaviour and 
chick growth in yellow nosed albatrosses. Mar Ecol Prog Ser 298:295 304

Pyke GH (1984) Optimal foraging theory: a critical review. Annu Rev Ecol Syst 15:523 575

R Development Core Team (2011) R: a language and environment for statistical computing. http://www.R project.org

Raymond B, Shaffer SA, Sokolov S, Woehler EJ, Costa DP, Einoder L, Hindell M, Hosie G, Pinkerton M, Sagar PM, Scott D, Smith A, Thompson DR, Vertigan C, Weimerskirch H (2010) Shear water foraging in the southern ocean: the roles of prey availability and winds. PLoS One 5(6):e10960. doi:10.1371/ journal.pone. 0010960

Rechten C (1985) The Waved Albatross in 1983: El Nino leads to complete breeding failure. In: Robinson G, del Pino EM (eds) El Nino in the Galápagos Islands: the 19821983 event. Charles Darwin Foundation for the Galápagos Islands, Quito, pp 227238

Shaffer SA, Costa DP, Weimerskirch H (2001) Behavioural factors affecting foraging effort of breeding wandering albatrosses. J Anim Ecol 70:864 874

Shepard ELC, Wilson RP, Quintana F, Gómez Laich A, Liebsch N, Albareda DA, Halsey LG, Gleiss A, Morgan DT, Myers AE, Newman C, Macdonald DW (2008) Identification of animal movement patterns using tri axial accelerometry. Endanger Species Res 10:47 60. doi:10.3354/esr00084

Suryan RM, Anderson DJ, Shaffer SA, Roby DD, Tremblay Y, Costa DP, Sievert PR, Sato F, Ozaki K, Balogh GR, Nakamura N
(2008) Wind, waves, and wing loading: morphological special ization may limit range expansion of endangered albatrosses. PLoS One 3:e4016

Wakefield ED, Phillips RA, Matthiopoulos J, Fukuda A, Higuchi H, Marshall GJ, Trathan PN (2009) Wind field and sex constrain the flight speeds of central place foraging albatrosses. Ecol Monogr 79:663 679

Weimerskirch H, Lys P (2000) Seasonal changes in the provisioning behaviour and mass of male and female wandering albatrosses in relation to the growth of their chick. Polar Biol 23:733 744

Weimerskirch H, Salamolard M, Sarrazin F, Jouventin P (1993) Foraging strategy of wandering albatrosses through the breeding season: a study using satellite telemetry. Auk 110:325 342

Weimerskirch H, Chastel O, Ackermann L, Chaurand T, Cuenot Chaillet F, Hindermeyer X, Judas J (1994) Alternate long and short foraging trips in pelagic seabird parents. Anim Behav 47:472 476

Weimerskirch H, Zimmermann L, Prince PA (2001) Influence of environmental variability on breeding effort in a long lived seabird, the yellow nosed albatross. Behav Ecol 12:22 30

Wilson RP, White CR, Quintana F, Halsey LG, Liebsch N, Martin GR, Butler PJ (2006) Moving towards acceleration for estimates of activity specific metabolic rate in free living animals: the case of the cormorant. J Anim Ecol 75:1081 1090

Wilson RP, Shepard ELC, Liebsch N (2008) Prying into the intimate details of animal lives: use of a daily diary on animals. Endang Species Res 4:123 137 